Review

\title{
Scope of whole genome duplication in forages: a plant breeder perspective
}

\author{
Saeed Rauf ${ }^{1}$, Rodomiro Ortiz ${ }^{2 *}$, Dariusz P. Malinowski ${ }^{3}$, Wellington Ronildo Clarindo ${ }^{4}$, Wardah \\ Kainat ${ }^{1}$, Muhammad Shehzad ${ }^{1}$, Ummara Waheed ${ }^{5}$, and Syed Wasim Hassan ${ }^{1}$ \\ ${ }_{1}^{1}$ Department of Plant Breeding and Genetics, College of Agriculture, University of Sargodha-P.O. Box, 40100, \\ Pakistan, saeedbreeder@hotmail.com, wardahkainat66@gmail.com, muhammad.shehzad@uos.edu.pk \\ whsyed61@gmail.com
}

${ }^{2}$ Department of Plant Breeding, Swedish University of Agricultural Sciences, Sundsvagen 10 Box 101, SE 23053 Alnarp, Sweden, rodomiro.ortiz@slu.se

3 Texas A\&M Agrilife Research, Texas A \& M University, P.O. Box 1658, Vernon, TX 76385, USA, dmalinow@ag.tamu.edu

4 Department of General Biology, Federal University of Viçosa, Viçosa, MG, ZIP36.570-900, Brazil, welbiologo@gmail.com

5 Institute of Biotechnology and Plant Breeding, MSN-University of Agriculture, Multan-Pakistan, ummara.waheed@mnsuam.edu.pk

*Correspondence: rodomiro.ortiz@slu.se

\begin{abstract}
Polyploidy is a condition of having more than two sets of chromosomes. Polyploid plants may be artificially obtained through chemical, physical and biological methods ( $2 n$ gametes). It is considered an interesting approach due to increased genescope and expression, thus resulting in phenotypic changes, such as yield and product quality. Nonetheless, breeding new cultivars through induced polyploidy should overcome deleterious effects partly contributed by genome and epigenome instability after polyploidization. Furthermore, shortening the time required from early chromosome set doubling to the final selection of high yielding superior polyploids is a must. Despite these hurdles, plant breeders have successfully obtained polyploid bred-germplasm in broad range of forages from optimized application methods, concentration and time mainly using colchicine. These experimental polyploids proved to be a valuable tool for understanding gene expression that is driven by dosage dependent gene expression, altered gene regulation and epigenetic changes. Isozymes and DNA-based markers aided on the identification of rare alleles for particular loci when compared with diploids, which may explain their heterozygosity, phenotypic plasticity and adaptability to diverse environments. It has also been observed that experimentally induced polyploid germplasm could enhance fresh herbage yield and quality, e.g. leaf protein content, leaf total soluble solids, water soluble carbohydrates and sucrose content. Offspring of experimentally obtained hybrids underwent selection for several generations to improve their performance and stability.
\end{abstract}

Keywords: Amphiploidy; Disomic Polyploidy; Plant Genome Evolution; Neo-polyploidy; Polysomic Polyploidy 


\section{Introduction}

Polyploidy is a condition of having more than two basic sets of chromosomes. It occurs among various life forms [1]. Polyploidy is the widely distributed phenomenon in wild and cultivated crops of forest, legume and grass forage species [2]. Whole genome duplications also occurred at very high rate in forages, e.g. $75 \%$ of the speciation underwent genome duplications in group of 1200 species [3].

The remarkable ecological success of the polyploidy prompts the breeders to develop new polyploid germplasm and with increased economic value [2]. These polyploids could also help to understand the evolution of various plant species with economic relevance. The polyploids are also used as bridging species to transfer resistant genes from their parental species, as genes related to biotic and abiotic stresses $[4,5]$. In contrast to natural polyploidy that have evolved as products of natural selection [6], induced polyploid (polysomic polyploids, and true or segmental allopolyploids) have been mainly developed from after the anti-tubulin effect mainly of the colchicine - (S)-N-(5,6,7,9-tetrahydro-1,2,3,10-tetramethoxy-9-oxobenzo[a]heptalen-7-yl) acetamide; and also of the oryzalin -3,5-dinitro- $\mathrm{N}^{4}, \mathrm{~N}^{4}$-dipropylsulfanilamide; trifluralin$\alpha, \alpha, \alpha$-trifluoro-2,6-dinitro-N,N,-dipropyl- $p$-toluidine; and amiprophos methyl-O-methyl O-(2-nitro- $p$-tolyl) $\mathrm{N}$-isopropyl phosphora midothionate) [7]. Besides, some polyploids have been also obtained after using physical agents, such as temperature shock, and by intra- (polysomic polyploidy) or interspecific (true or segmental amphiploidy) crossing.

Artificial polyploidy was developed in 1937 after discovery and extraction of the natural compound named as colchicine. The colchicine has the ability to inhibit spindle fiber formation to arrest the chromosome, causing a failure of chromatid disjunction [8] and of cytokinesis [7]. Spontaneous chromosome set doubling also occurs in plant somatic cells, and gametes at low frequency, which may subsequently result in a polyploid organism [9] by vegetative or seminal propagation, respectively.

Natural and induced polyploid have been widely investigated in crops, fruits, trees, ornamentals, forages and medicinal plants [10]. This research was pursued to address $21^{\text {st }}$ century challenges related to continuous population growth, as well as the global climate change [11]. Forages have been widely exploited for their vegetative biomass that may be used as feed for animals and show a great potential for becoming biofuel crops [12]. Polyploidy is widely distributed phenomenon among forage species $[3,13,14]$ and may be induced in diploid species to improve biomass productivity and its nutritional characteristics. We review various methods and approaches for developing polyploid germplasm and species with chemicals and their commercial importance when compared with ancestral and natural polyploid species.

\section{Production of polyploid plants}

Polyploid plants (polysomic polyploids, true and segmental amphidiploids) can be produced using various chemicals, such as colchicine, amiprophos-methyl, trifluralin or oryzalin; or physical methods such as temperature shock and protoplast fusion [8]. The most common chemical is colchicine obtained from Colchicum autumnale, which has an inhibitory effect on the spindle formation, causing a failure during anaphase disjunction [8] and during cytokinesis [7], resulting in one cell with the doubled chromosome set. Hence, colchicine treatment results in pure polyploid individuals and impure (mixoploid or with aneuploid cells), depending upon the colchicine concentration and exposure time, plant tissues and its development stage, and method for 
chromosome set doubling. Colchicine solution may be applied to the immature buds, resulting in the production of unreduced reproductive cells and, subsequently, produce polyploidy seed in different rates. It is applied to the pedicel of growing immature bud or the inflorescence stalk may be dipped in the growth media solution with a low concentration of colchicine (0.01 to $0.1 \%$ ), depending upon the forage species (Table 1). Cotton swab dipped in colchicine solution of $0.2 \%$ for $10 \mathrm{~h}$ and consecutive 2 days successfully induced a polysomic tetraploid (12-40\%) in guar accessions [15]. Colchicine can also be applied to the callus; i.e., cell culture of meristematic tissues to produce chimeric plants, or seed may be germinated in colchicine solution [16]. Generally, colchicine (0.1-1\%) has been applied to seeds for 24-48h depending upon the forage species to target cells undergoing mitosis (Table 1). Growth arrest is the first symptoms of successful application of colchicine (Fig. 1). Affected cells usually resume division after a lag period of colchicine application. A comparison of euploid series $(2 \times, 4 \times, 6 \times$ and $8 \times)$ in Arabidopsis thaliana showed that induced polyploidy had slower growth, had increased cell size, and lower number of cells per leaf blade. Polyploid cells had lower lignin and cellulose but higher pectin and hemicelluloses in the stem [17]. Frequency of the polyploidy induction can increase with the increase of the colchicine concentration (Table 1). A high colchicine concentration has been, however, toxic to cell and plant tissues. A low colchicine concentration $(0.1 \%)$ treatment with relative long duration $(48 \mathrm{~h})$ has been effective in increasing the yield of polyploid cells in shoot tips in vitro [18] (Table 1). For instance, sorghum seed were subjected to $0.2 \%$ concentration of colchicine for $48 \mathrm{~h}$ and $72 \mathrm{~h}$, yielding $3.3 \%$ and $2.3 \%$ polysomic tetraploid plants, respectively [19]. A direct application of colchicine by dipping the apical meristem of seedlings was shown to produce chimeric tissues where induced polyploidy was limited to a particular layer [20].

Polyploid plants can be produced through somatic cell fusion [21]. This method has been used to fuse the protoplast of the same species (polysomic polyploidy) or of two species (amphiploidy or disomic polyploidy) in electric shock chamber without reduction division and it has been successful in creating amphidiploid forage species [22].

In vitro induction of polyploidy was successfully achieved by culturing the nodal segments or callus in tissue culture media supplemented with a low concentration of colchicine. This method has been shown to induce high frequency of polyploidy in various species (Table 1). In comparison with the doubling agents, oryzalin was found to show higher frequency of the induced polyploidy over colchicine [23], but it inhibited the callus growth and seedling regeneration. Liquid medium was more effective in inducing the polyploidy when compared with semi solid media [7, 23]. A concentration of $5 \mu \mathrm{m}$ oryzalin was found highly effective over colchicine and trifluralin in inducing chromosome set doubling of calli obtained from interspecific hybrid plants of elephant grass $\times$ pearl millet [24]. In vitro treatment of Trifolium pretense yielded 55.5\% higher number of polysomic tetraploids and 1.9 times fewer chimeric individuals when compared with seed imbibition in colchicine solution $[25,26]$. Colchicine, amiprophosmethyl and oryzalin produced similar frequency of polysomic tetraploid (31-47\%) and chimeric plants (14-22\%) in T. pratense [25]. Colchicine $(0.015 \%$ in tissue culture media) was more effective in inducing polysomic tetraploidy (16\%) in Trifolium polymorphism species when compared with oryzalin [27].

The demand for pure polyploids and due to different ploidy levels obtained after chromosome set doubling the screening, selection and periodic evaluation of the ploidy level stability of the natural and induced polyploids are needed [28]. Nowadays, the main used method for these 
purposes is the flow cytometry $[8,29]$ that increases the efficiency of the DNA ploidy level determination and nuclear genome size measurement. From flow cytometry, large numbers of individuals are quickly evaluated in only one day in a quantitative, thus being rapid, reliable and reproducible [11]. This powerful screening tool for ploidy level has been very useful in forage breeding programs. However, the chromosome counting, which is performed through microscopic observation of the metaphase cells, has been also applied to confirm the chromosome number $[8,28$, 29], and, consequently, the ploidy level and detect eventual aneuploids. For example, chromosome counting was only method used to identify polysomic tetraploid and aneuploid plantlets regenerated through direct and indirect somatic embryogenesis of Lilium cernuum Komar and Lilium distichum Nakai, respectively, after colchicine treatment [30]. In relation to flow cytometry (nuclear ploidy level), chromosome number was most adequate to characterize the karyotype and, thus, identify polyploid and few aneuploid (hyperploid and hypoploid) cultivars of Phalaenopsis [31]. Besides these direct tools, indirect analyses have been accomplished. The effects of induced polyploidy on forage species were an increase in the stomatal area and decrease in the stomatal frequency. These changes in the leaf anatomy were due to increase in cell volume promoted by increase in nuclear DNA content [32].

Table 1. Recovery of induced tetraploids using various concentrations of anti-mitotic treatments

\begin{tabular}{|c|c|c|c|c|}
\hline Species & Ploidy level & Treatment & $\begin{array}{l}\text { Polyploid } \\
\text { frequency }\end{array}$ & References \\
\hline Vicia faba & $2 \times=12$ & $\begin{array}{l}0.005 \% \text { for } 8 \mathrm{~h} \text {, seed } \\
\text { imbibition }\end{array}$ & $4 \times=50 \%$ & [33] \\
\hline $\begin{array}{l}\text { Cyamopsis } \\
\text { tetragonoloba }\end{array}$ & $2 x=14$ & $\begin{array}{l}0.2 \% \text { cotton swab for } \\
10 \mathrm{~h} \text {, }\end{array}$ & $4 \times=12-40 \%$ & [15] \\
\hline $\begin{array}{l}\text { Pennisetum } \\
\text { purpureum } \times \\
\text { Pennisetum glaucum }\end{array}$ & $3 x=21$ & $\begin{array}{l}\text { In vitro colchicine } \\
(0.1 \%) \text { solution, seed } \\
\text { imbibition }\end{array}$ & $\begin{array}{l}6 \times=17 / 480, \text { larger } \\
\text { stomata size }\end{array}$ & [91] \\
\hline Brachiaria ruziziensis & $2 \times=18$ & $\begin{array}{l}\text { Invitro } \quad 0.0125-0.1 \% \\
\text { colchicine }\end{array}$ & $\begin{array}{l}4 \times=23 / 400 \\
(31.3 \%) \quad 0.1 \% \\
\text { colchicine for } 3 \text { BAP }\end{array}$ & {$[92]$} \\
\hline $\begin{array}{l}\text { Miscanthus } \times \\
\text { giganteus }\end{array}$ & $3 x=57$ & 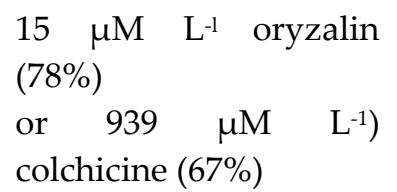 & $\begin{array}{l}6 \times \quad \text { were induced } \\
\text { successfully }\end{array}$ & [23] \\
\hline Brachiari adecumbens & $\begin{array}{l}2 \times=18,36 \\
45\end{array}$ & $\begin{array}{l}\text { Colchicine } \\
\text { concentration }(0.01 \% \text {, } \\
0.01 \% \text {, and } 0.1 \%)\end{array}$ & $\begin{array}{l}0.1 \% \text { colchicine for } \\
48 \mathrm{~h} \text { induces } 11 \% \text { of } \\
\text { polyploid }\end{array}$ & [20] \\
\hline Miscanthus species & $2 x=38$ & $\begin{array}{l}\text { Callus treatment with } \\
313-626 \mu \mathrm{M} \text { colchicine }\end{array}$ & $\begin{array}{l}4 \times \text { was induced with } \\
40 \% \text { success } \\
4 \times=53.58 \%\end{array}$ & [93] \\
\hline $\begin{array}{l}\text { Psathyrosta } \\
\text { chysjunceus }\end{array}$ & $2 x=14$ & $\begin{array}{l}100 \mathrm{mg} \mathrm{L} \mathrm{L}^{1} \text { colchicine } \\
\text { and } 1.5 \% \mathrm{DMSO} \text {, callus } \\
\text { tissue }\end{array}$ & $\begin{array}{lr}\text { Stomata } & \text { size } \\
\text { increased by } & 13.52 \% \\
\text { while stomata } \\
\text { frequency decreased }\end{array}$ & [32] \\
\hline Lolium multiflorum & $2 x=14$ & $\begin{array}{l}\text { Seedling immersion } \\
(0.2 \%) \text { for } 3 \mathrm{~h} \text { and } 24 \mathrm{~h} \text { in } \\
\text { colchicine }\end{array}$ & $4 \times=20 \%$ & [61] \\
\hline Brachiaria ruziziensis & $2 \times=18$ & $0.1 \%$ colchicine, seed & $4 \times=11.45 \%$ & [94] \\
\hline Sorghum bicolor & $2 x=20$ & MS medium & Invitro & [18] \\
\hline
\end{tabular}




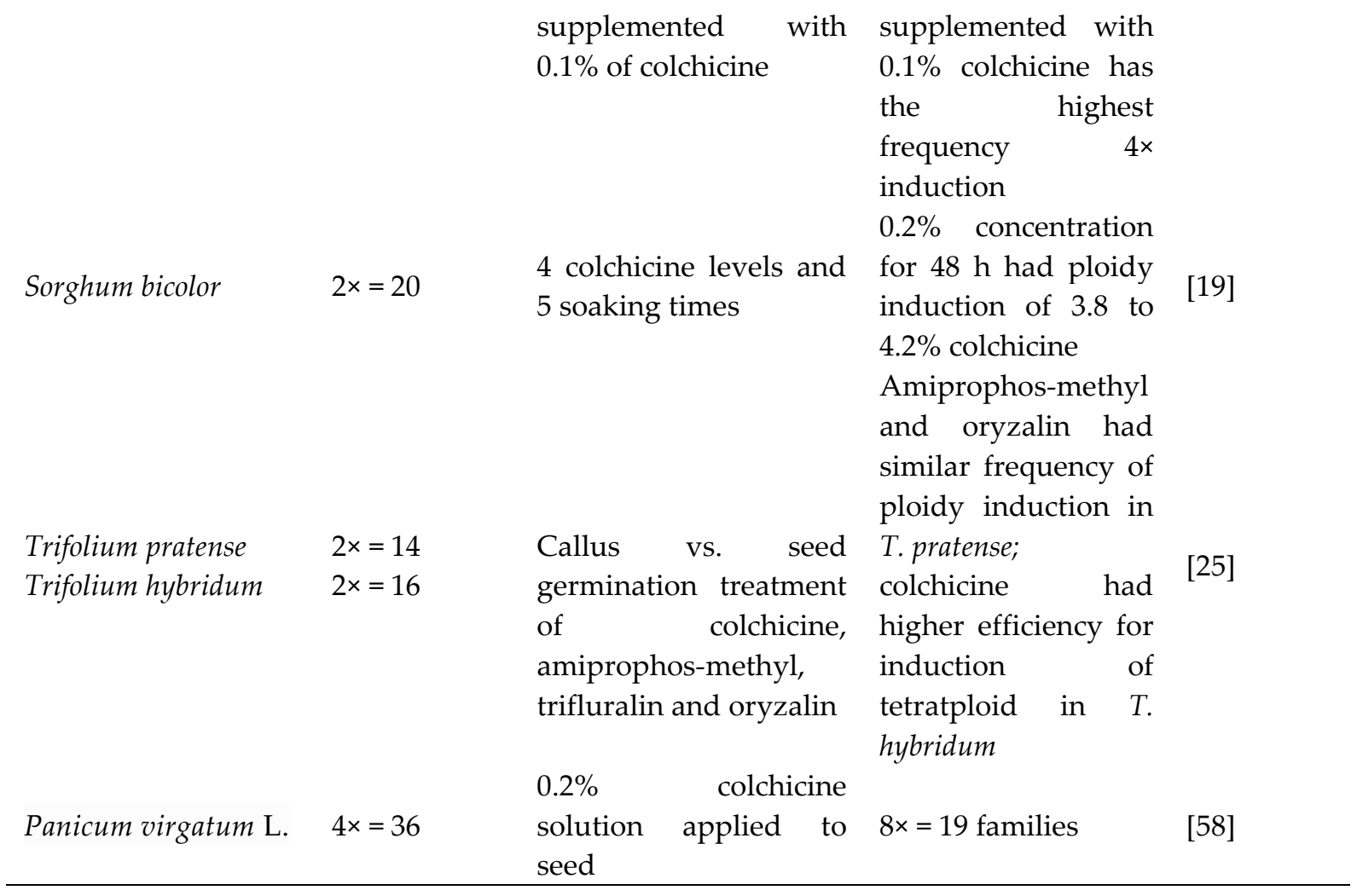

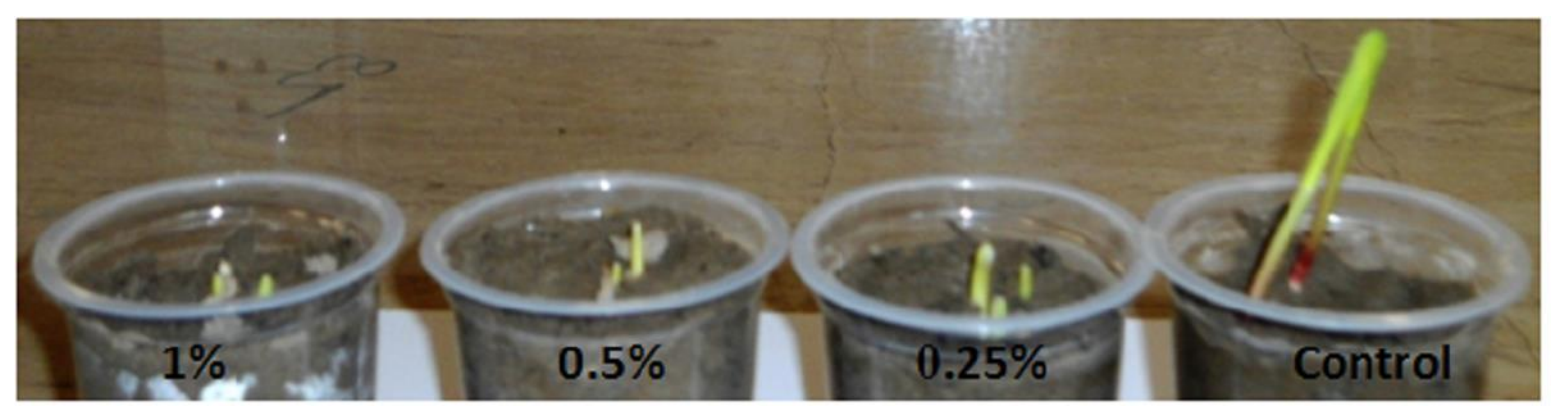

Figure 1. Control vs. various treatments of colchicine $(0.25-1 \%)$ in growth of interspecific maize $\times$ teosinte seedlings after treatment of seeds for 24 hours (Niazi, I.A.K., permission granted). 


\section{Impact of Polyploidy on Forage Yield and Contributing Traits}

There are numerous positive effects of induced polyploidy when compared with diploidy; i.e., larger leaves, herbage yield and slow decay of heterosis [10, 33] (Table 2), increase in plant height, persistence, faster re-growth after grazing and increased branching of various forage species were noted in the former [34] (Table 2). Potential benefits of induced polyploidy of various forage species are noted in Table 2. Disomic tetraploid intersubspecific hybrids (maize $\times$ teosinte) had $14 \%$ biomass yield increase over their diploid counterpart [16]. Other advantage of tetraploid hybrids included greater leaf area, leaf essential oil contents, and protein contents [16]. Polysomic tetraploid of Lolium species had slow decay of heterosis and has the potential to give better seed yield over several generations without significant decrease in their forage yield and thus their cultivation could be done with cheaper seed that could overcome the drawback of expensive F1 seed [35]. However, chromosome doubling reduced the persistence in the induced $4 \times$ ryegrass [35]. Research has shown that neo polyploids have increased production of secondary metabolites, thus enhancing forage quality, succulence and forage intake [36]. Induced polyploids had often poor seed setting and higher pollen sterility [33]. Polysomic tetraploid $(4 \times)$ were compared with diploids $(2 \times)$ plants in Vicia villosa roth and induced polysomic tetraploid plants of the species were dwarf with greater leaf area, stomatal diameter, higher chlorophyll contents, but the polysomic tetraploid delayed and lesser flowering than diploid counterparts [37]. Reconstituted polysomic tetraploid (4×) of Festuca pratensis had $26 \%$ dry matter and $100 \%$ seed yield advantage over standard check cultivars [25]. For some forage species; i.e., as Dactylis polygama and Lolium perenne, polysomic tetraploids did not differ in biomass yield from diploids but they were superior in terms of forage intake [38] and other forage quality parameters [39]. A patent of triploid ( $3 \times$ superior over $4 \times$ and $2 \times$ ) maize has been awarded to produce high molasses, rum and fodder in low sterile genotype [106, 107].

Table 2. Impact of induced polyploidy on forage traits in various species

\begin{tabular}{|c|c|c|}
\hline Species & Characteristics & References \\
\hline Sorghum bicolor & $\begin{array}{l}4 \times \text { pollen had lower germination percentage and pollen } \\
\text { tube growth than diploid pollens resulting in lower seed } \\
\text { setting percentages }\end{array}$ & [95] \\
\hline Lolium perenne & $\begin{array}{l}4 \times \text { had larger and wider leaves, taller seedlings, and } \\
\text { fewer tillers }\end{array}$ & [79] \\
\hline Dracocephalum moldavica & $4 \times$ had $27.5 \%$ higher essential oils & [96] \\
\hline Trifolium alexandrinum & $\begin{array}{l}\text { Induced } 4 \times \text { had taller plants, faster regrowth, increased } \\
\text { tillering and branching }\end{array}$ & [34] \\
\hline Sorghum bicolor & $\begin{array}{l}4 \times \text { had thicker leaves, taller plantslonger leaves, higher } \\
\text { antioxidant activity, panicle length and diameter }\end{array}$ & [97] \\
\hline Sorghum bicolor & $\begin{array}{l}4 \times \text { had higher chlorophyll contents, water soluble } \\
\text { carbohydrates, and proteins }\end{array}$ & [18] \\
\hline $\begin{array}{l}\text { Zea mays } \times \text { Zea mays ssp. } \\
\text { mexicana } \\
\text { Zea mays }\end{array}$ & $\begin{array}{l}4 \times \text { had higher leaf soluble proteins, oil contents, and } \\
\text { total soluble sugars }\end{array}$ & [16] \\
\hline Trifolium alexandrinum & $4 \times$ had better pentafoliate trait than $2 \times$ & [98] \\
\hline $\begin{array}{l}\text { Lolium multiflorum, Lolium } \\
\text { perenne and Festuca } \\
\text { pratensis }\end{array}$ & $\begin{array}{l}4 \times \text { produced higher dry matter and seed yield when } \\
\text { compared with } 2 \times \text { and may be used for the development } \\
\text { of new cultivars }\end{array}$ & [26] \\
\hline
\end{tabular}



decreased. Leaf anatomy was used to discriminate $2 \times$ vs. [99] $3 \times$ accessions

$2 \times=$ diploid, $3 \times=$ triploid, $4 \times=$ tetraploid

\section{Genetics of Polyploidy}

Polysomic polyploid species differ from disomic polyploid (or amphidiploid) species due to their inheritance. The amphidiploid species show peculiar disomic inheritance for locus behaves similar to diploids. Polysomic tetraploid species show quadrivalent (multivalent) pairing, which requires chromosome homology andmay end up in double reductions during meiosis II [40]. Polysomic polyploids may have four copies of alleles (Fig. 2), where two extra copies of alleles were considered as fuel for evolution, because these alleles may undergo the process of sub-functionalization or neofunctionalization [41]. Sub-functionalization and neofunctionalization of alleles may lead to the homoeologous chromosome that may enhance preferential pairing of fully homologous chromosome leading to suppression of quadrivalent pairing. There is a challenge for forage breeder to identify various tetrasomic genotypes \{i.e., AAAA (quadriplex), AAAa (triplex), AAaa (duplex), Aaaa (simplex) and aaaa (nulliplex)\} and confirm polysomic tetraploidy. Isozyme analysis in ryegrass using two markers loci; i.e., the aspartate aminotransferase and the NAD-specific aromatic alcohol dehydrogenase, showed two alleles per locus and could be used to distinguish heterozygous or homozygous genotypes due to co-dominance of marker alleles [42]. Thus, these isozymes in this study were only able to uncover two alleles per locus in the polyploid ryegrass. Isozyme analysis showed allelic diversity due to polymorphism in enzymatic structure which may be used to differentiate various tetrasomic genotypes in various polysomic tetraploid alfalfa populations [43]. Esterase enzyme characterized alfalfa synthetic populations into tri-allelic ( $\left.b_{1} b_{2} b_{3}\right)$ and di-allelic ( $b_{3} b_{3} b_{3} b_{2}, b_{3} b_{3} b_{1} b_{1}$ ) at locus EST-B [43] (Valizadeh et al., 2011). Phosphoglucomutase (PGM) enzyme was controlled by two locus Pgm-1 and Pgm-2 while Isocitrate dehydrogenase was controlled by asingle locus $(I D H)$. Each locus showed tetrasomic inheritance in polysomic tetraploid alfalfa [44]. Both enzymes showed diversity in their maker allele size and were successfully used for the identification of tetrasomic genotypes in alfalfa [44]. Tetraploid alfalfa contained three alleles a', a and $\mathrm{b}$ for $p g m-1$. Polysomic tetraploid genotypes contained rare allele $\mathrm{a}^{\prime}$ that was absent in diploid, but was carried in various tetrasomic combinations. Genotype a'a'aa (duplex) was the most frequent. Functional diversity in isozyme alleles at single locus explains the phenotypic plasticity, high level diversity, and more heterozygosity that may provide an adaptability advantage over diploids [44]. Isozyme allelic diversity such as EST-B and POX-b2 was related with fresh leaf weight in alfalfa [45].

DNA-based molecular makers such as amplified fragment length polymorphism (AFLP) were applied to confirm tetrasomic inheritance in tetraploid forage legume species (Lotus corniculatus), which show suppressed quadrivalent pairing. AFLP successfully confirmed the tetrasomic inheritance prevailing in the species, providing evidence of polysomic tetraploid classification of this species [46]. Similarly, tetrasomic inheritance was also confirmed in the other forage species such as alfalfa, the Paspalum using DNA-based molecular markers systems [47, 48, 49]. Microsatellite (SSR) markers (MAA660456, MTIC343, MTIC354, MTIC365) identified all four alleles at specific loci in polysomic tetraploid alfalfa cultivars. Marker (MTIC365) characterized alfalfa cultivars Mercedes4.11 as tetra-allelic (ABCD) and Magali2 as tri-allelic (ABCC) [48]. 
Polysomic tetraploids were difficult as breeding material and shows low decay of heterozygosity, a high degree of inbreeding depression and disomic - tetrasomic inheritance of alleles at single locus [16, 50]. The use of DNA-based molecular markers may help to identify various tetrasomic genotypes, to select appropriate parental breeding lines. MAS may help to exploit maximum heterozygosity at single loci to improve the performance of tetraploid genotypes.

a.

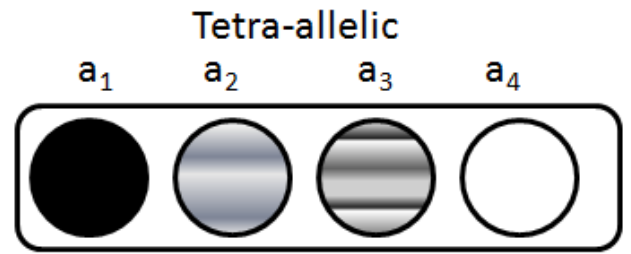

Tri-allelic

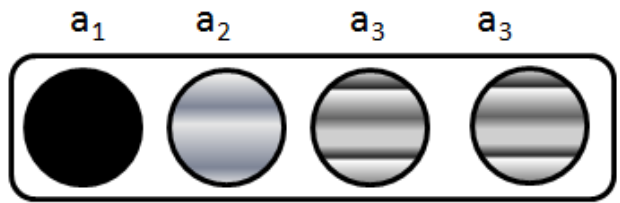

Balanced di-allelic

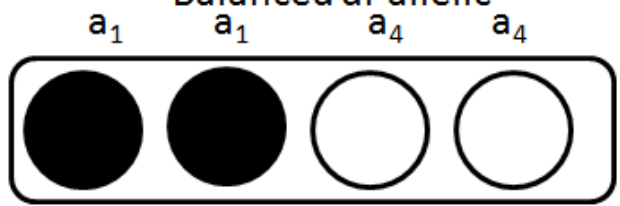

Unbalanced di-allelic

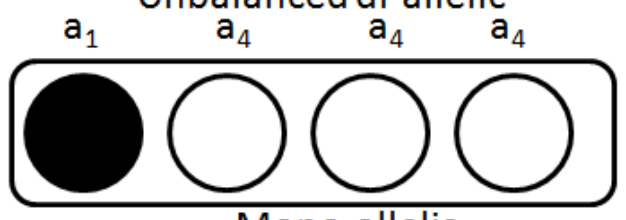

Mono-allelic

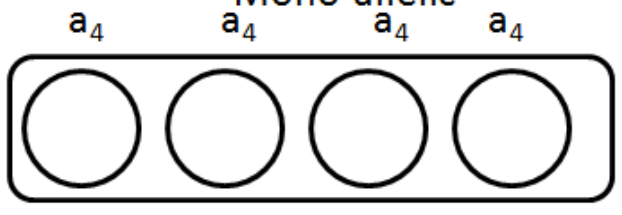

Tetrasomicinheritance b.

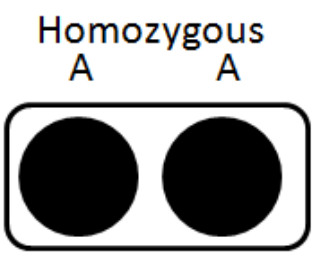

heterozygous

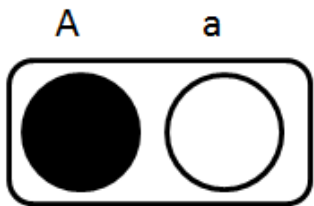

Homozygous

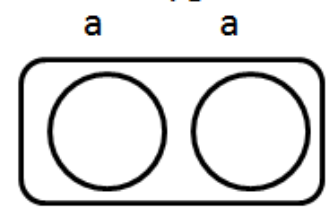

Disomic inheritance

Figure 2. Conceptual diversification of inheritance of five tetrasomic genotypes assuming sub-functionalization (a) and disomic inheritance in three diploid genotypes (b).

\section{4. "OMICS" Analysis of Polyploidy}

Metabolic comparison between forage plants with distinct ploidy level was accomplished by [51]. In comparison to diploid alfalfa, authors evidenced that polysomic tetraploid and polysomic octoploid protoplasts showed the respective nuclear genome size (i.e., confirming $4 \times$ and $8 \times$ ), and, consequently, higher amount of the ribulose-1,5-bisphosphate carboxylase / oxygenase and chlorophyll. For non-forage species, the evaluations about transcriptome and physiology effects after induced chromosome set doubling have been also performed. In addition to morphologic changes, the L. distichum polysomic tetraploids showed higher stomatal conductance than diploid ones, while L. cernuum polysomic tetraploids presented lower stomatal conductance [30]. An increase in chlorophyll content was also detected in polyploids, which resulted in darker green leaves [52]. The "gigas effect" about the morphological and physiological traits of the polysomic tetraploids Raphunus sativus L. was confirmed after comparing to the diploids, and also differences 
in the endogenous phytohormone levels and flowering genes expression carried out to delay in the flowering and bolting in the polysomic tetraploids [53]. Rao et al. [4] reported that the induced polysomic tetraploidy in Lycium ruthenicum resulted plants that exhibited increase in abscisic acid content in relation to the diploid counterparts due to doubled gene copy and upregulated of the 9-cis-epoxycarotenoid dioxygenase 1 and 9-cis-epoxycarotenoid dioxygenase 2 genes involved with this hormone biosynthesis. The increase in abscisic acid in the polysomic tetraploids also upregulated the ABRE-binding factor 5-like gene and genes that codified osmotic proteins, increasing the drought resistance in relation to the diploids. Induced polyploidy resulted in epigenetic outcomes in alfalfa (Medicago sativa), changing the expression of 189 genes [54]. Brachiaria genus possesses species with diferent basic chromosomes number $(x=6$ to $x=9)$ with polyploid origin. The occurence, mapping and distribution of the gypsy retrotranposons in the karyotype of Brachiaria decumbens, Brachiaria brizantha, Brachiaria ruziziensis and Brachiaria humidicola evidenced that, besides the chromosome number variation, mobile elements also contributed to the karyotype evolution [55]. In addition, genetic variation was showed in polyploid Paspalum species from SSR markers developed for this genus.

As the forage are also affected by abiotic and biotic stresses, interfering in the several traits, the "omics "differences, mainly the transcriptome and metabolome, should be investigated and compared between the ancestor diploids and its induced polyploids. The future approaches involving induced polyploid forage may also include analyses to show the interference of the nuclear gene copy increase in organellar genes expression, both mitochondrial and plastidial, like explored by [56] Oberprieler et al. in diploid, tetraploid, and hexaploid species of Leucanthemum Mill.

\section{Restoration of Fertility}

Induced polyploidy has been used as tool to restore the fertility of interspecific hybrids with different ploidy levels or distinct genomes with similar levels, mainly homoploids and anorthoploids. Fertility of allotriploid hybrids between the Pennisetum purpureum and Pennisetum glaucum was restored by germinating the seed in [57] medium supplemented with colchicine. Induced polyploidy in homoploid interspecific (Zea mays $\times$ Zea mays ssp. mexicana) hybrids resulted in higher seed yield than that of diploid crosses when subjected to selection for the regular bivalent formation in maize [16]. Caryopsis and cell size of octoploid Panicum virgatum L. increased and the anatomy of the leaf tissues was changed when compared with diploid individuals, while fertility of the induced plants was decreased significantly [58]. Allotriploid hybrids of Miscanthus $\times$ giganteus were sterile but had higher biomass potential and persistence when compared with diploids. Poly-disomic hexaploidy was induced to restore fertility in these allotriploid hybrids and reduce the cost of hybrid seed production [23]. Induced disomic tetraploidy in maize $\times$ teosinte hybrids followed by selection for quadrivalent and bivalent formation in induced tetraploid also led to the decrease in hybrid vigor decay, which was investigated throughout various generations [16].

\section{Stability of The Induced Polyploidy}

Evolutive research findings suggest that many diploid plant species originated as polyploids and reversed to diploid (Mendelian genetics) forms due to a gradual loss of chromosome during synapsis between homologous (polysomic polyploidy) or homoeologous (amphipolyploidy or 
disomic polyploidy) chromosomes. These species failed to develop a genetic mechanism to enhance bivalent pairing and to suppress univalent or multivalent pairing of the homologous or homoeologous chromosomes. The failure of regular bivalent pairing and disjunction resulted in a larger frequency of aneuploid gametes that increased the gametophytic sterility.

The chromosome number stability counting in various generation after induced tetraploid $\left(\mathrm{C}_{1}-\right.$ $C_{2}$ ) indicated an increase in the aneuploid form in $C_{2}(55 \%)$ when compared with $C_{1}(2.5 \%)$ generation [64]. In Brachiaria brizantha, failures in spindle fibers formation and absence of metaphase plate were noted in the induced polyploids, as well as micro nuclei were observed in subsequent generation showing abnormalities in meiotic divisions [59]. Homoploid Pennisetum purpureum $\times$ Pennisetum glaucum showed alteration in karyotypes, as chromosomal rearrangement and loss of DNA sequences, thus evidencing that interspecific hybrids show intergenomic conflicts which may lead to the loss of the genomic DNA [60], including genes and DNA sequences of the centromere and telomere. Contrary to these findings, induced polysomic tetraploids of Lolium multiflorum showed stability in chromosome number in subsequent generations [61]. Selection for large pollen (2×) production in red clover (Trifolium pratense) increased this trait 4 to $8.9 \%$ from $C_{1}$ to $C_{4}$, respectively, thus increasing polysomic tetraploid production in subsequent generations [62]. Selection for genotypes with a frequent capacity for quadrivalent pairing in induced tetraploid of maize resulted in a significant reduction in aneuploids and associated pollen sterility [63]. As a result of the selection for quadrivalent formation, the univalent and trivalent formation significantly decreased with corresponding increase in the bivalent and quadrivalent pairing (Table 3).The selection process led to an increase in the seed yield, whereas herbage yield was affected in $4^{\text {th }}$ generation of self-pollinated tetraploids (Table 3). Polysomic tetraploid recovery increased over various generations of Lolium perenne L. of selection; i.e., $C_{1}$ had $25 \%$ tetraploid, while self-pollination (4×) led to the recovery of $43 \%$ tetraploid [64].

Table 3. Chromosome pairing oftetraploid $(4 \times)$ offspring of maize selected for quadrivalent behavior [63]

\begin{tabular}{|c|c|c|c|c|c|c|}
\hline \multirow[b]{2}{*}{ Progenies } & \multirow[b]{2}{*}{$\begin{array}{c}\text { Univalents } \\
\text { (I) }\end{array}$} & \multicolumn{2}{|c|}{ Number of } & \multirow[b]{2}{*}{$\begin{array}{l}\text { Quadrivalents } \\
\text { (IV) }\end{array}$} & \multirow{2}{*}{$\begin{array}{c}\text { Forage yield } \\
{\left(\mathrm{g}_{\text {plant }}^{-1}\right)}\end{array}$} & \multirow[b]{2}{*}{ Seed setting (\%) } \\
\hline & & $\begin{array}{c}\text { Bivalents } \\
\text { (II) }\end{array}$ & $\begin{array}{c}\text { Trivalents } \\
\text { (III) }\end{array}$ & & & \\
\hline S1-2x & - & 10 & - & - & $241.34^{\mathrm{b}} \pm 42.64$ & $98.13^{\mathrm{a}} \pm 2.01$ \\
\hline $\mathrm{C}_{1}-4 \times$ & $2.81^{\mathrm{a}} \pm 0.39$ & $1.52 \_ \pm 0.22$ & $3.11^{\mathrm{a}} \pm 0.41$ & $6.12^{\mathrm{d}} \pm 0.37$ & $321.55^{a} \pm 36.55$ & $26.19^{\mathrm{d}} \pm 4.12$ \\
\hline $\mathrm{C}_{2}-4 \times$ & $2.21^{\mathrm{b} \pm 0.42}$ & $1.84^{\mathrm{b} \pm 0.34}$ & $2.19^{b} \pm 0.29$ & $6.88^{c} \pm 0.74$ & $334.42^{\mathrm{a}} \pm 44.37$ & $29.27 \mathrm{~d} \pm 2.06$ \\
\hline $\mathrm{C}_{3}-4 \times$ & $1.51^{\mathrm{c} \pm 0.21}$ & $2.02 \mathrm{a} \pm 0.42$ & $1.14 \mathrm{c} \pm 0.33$ & $7.58^{b} \pm 0.52$ & $339.27 \mathrm{a} \pm 36.34$ & $41.23 \pm \pm 5.01$ \\
\hline $\mathrm{C}_{4}-4 \times$ & $0.81^{\mathrm{d}} \pm 0.17$ & $2.06^{\mathrm{a}} \pm 0.27$ & $0.54^{\mathrm{d}} \pm 0.21$ & $8.32^{\mathrm{a}} \pm 0.43$ & $351.21^{\mathrm{a}} \pm 40.19$ & $71.40^{\mathrm{b}} \pm 3.71$ \\
\hline
\end{tabular}

Means with similar letters are not statistically different $(P \geq 0.05) . C_{1}, C_{2}, C_{3}$ and $C_{4}$ are induced polyploid $(4 \times)$ offspring self-pollinated for four subsequent generations.

\section{Stress Tolerance of The Induced Polyploidy}

The benefits of the induced polyploidy, including polysomic and disomic polyploidy, have been often correlated with increased abiotic and biotic stress tolerance $[65,66]$ (Table 4). Higher tolerance 
to stress may directly result from induced polysomic polyploidy, which can increase the allelic copies for particular loci, thus increases gene expression and regulatory mechanisms for stress response [1]. Tetraploid species have been considered physiologically efficient due to improved gas exchange characteristics; i.e., carbon exchange rates, water use efficiency, transpiration and stomatal conductance [67] (Table 4). Natural polysomic tetraploid population of Rhodes grass (Chloris gayana L.) retained higher genetic diversity than the diploid form, which could help express diversified mechanisms for adaptation to salinity stress [68]. In contrast, polysomic tetraploid Lolium perenne expressed lower persistence than its diploid form due to lower root biomass and profuse tillering [69]. However, there were no differences between the diploid and tetraploid versions of Lolium perenne cv. 'Alto' in terms of water deficit and invertebrate tolerance [69]. In another study, induced polysomic tetraploid of Lolium perenne had higher competitive ability but lower tolerance to water deficit [70]. Different species of genus Cenchrus differ in their ploidy levels that include diploids, tetraploids and hexaploids. Tetraploid and hexaploid species had better gas exchange traits and morphological traits such as leaf rolling, wilting and plant height than diploid species [71]. Moreover, tetraploid and hexaploid species had better drought recovery than diploid species [71].

Table 4. Response of natural and induced polyploidy to various abiotic stress conditions and endophytic fungi interactions

\begin{tabular}{|c|c|c|c|}
\hline Stress & Species & Resistance & Reference \\
\hline $\begin{array}{l}\text { Water stress } \\
\text { tolerance }\end{array}$ & $\begin{array}{l}\text { Lolium multiflorum and Lolium } \\
\text { perenne }\end{array}$ & $\begin{array}{l}\text { Polyploid had better tolerance than } \\
2 \times \text { species }\end{array}$ & [100] \\
\hline $\begin{array}{l}\text { Aluminum } \\
\text { tolerance } \\
(16 \mathrm{mM} \\
\mathrm{Al}_{2}\left(\mathrm{SO}_{4}\right)_{3}\end{array}$ & $\begin{array}{l}16 \text { polyploid vs. diploid } \\
\text { species }\end{array}$ & $\begin{array}{l}\text { Polyploidy was positively related } \\
\text { with the stress tolerance index }\end{array}$ & {$[101]$} \\
\hline $\begin{array}{l}\text { Water stress } \\
\text { tolerance }\end{array}$ & Eight Cenchrus species & $\begin{array}{l}\text { Morphological traits such as plant } \\
\text { height, leaf rolling and wilting } \\
\text { indicated higher water stress } \\
\text { tolerance in natural polysomic } \\
\text { tetraploid species }\end{array}$ & {$[71]$} \\
\hline Salt stress & Trigonellafoenumgreaum & $\begin{array}{l}\text { Neo-polyploploids showed higher } \\
\text { values of forage traits under salt } \\
\text { stress }\end{array}$ & {$[102]$} \\
\hline Salinity & Brassica rapa & $\begin{array}{l}4 \times \text { plant species had better } \\
\text { germination under salinity stress } \\
\text { and maintained higher } \mathrm{K}^{+} / \mathrm{Na}^{+} \text {ratio } \\
\text { in roots and shoots }\end{array}$ & {$[103]$} \\
\hline Salinity & Chloris gayana (Rhodes grass) & $\begin{array}{l}\text { Wild genetic diversity in tetraploid } \\
\text { species may be useful for making } \\
\text { selection for salinity tolerance }\end{array}$ & {$[68]$} \\
\hline $\begin{array}{l}\text { Endophytic } \\
\text { fungi }\end{array}$ & $\begin{array}{l}\text { Lolium multiflorum and } \\
\text { Bromus }\end{array}$ & $\begin{array}{l}2 \times \text { species had higher endophytic } \\
\text { infection rate than } 4 \times\end{array}$ & [105] \\
\hline $\begin{array}{l}\text { Cold and } \\
\text { drought stress }\end{array}$ & Ryegrass(Lolium perenne) & $\begin{array}{l}4 \times \text { species had better tolerance to } \\
\text { cold and drought tolerance, higher } \\
\text { regrowth and high dry matter yield }\end{array}$ & [106] \\
\hline Drought stress & Ryegrass(Lolium perenne) & $\begin{array}{l}\text { Greater biomass yield under } \\
\text { drought stress }\end{array}$ & [108] \\
\hline
\end{tabular}

$2 \times=$ diploid, $4 \times=$ tetraploid 
Tetraploid and diploid versions of Cenchrus species also differ in the antioxidant system. The tetraploid species had more efficient and expressive antioxidant system (higher values for $\Delta^{1}$-pyrroline-5-carboxylate synthetase) to scavenge the reactive oxygen species under water stress which may be translated in higher tolerance to water stress [71, 104]. Polysomic tetraploid black locust (Robinia pseudoacacia L.) showed superiority over diploid due to higher defense related enzymatic activity and maintenance of photosynthesis rate under salinity stress [72]. Disomic polyploidy can indirectly improve stress tolerance as the amphidiploids combining a commercially important but susceptible diploid species with a highly resistant species, followed by a doubling of the chromosome number. Triticale is a human-made species originating from the hybridization between tetraploid self-pollinated species wheat (Triticum durum), and diploid outcrossing species rye (Secale cereale), with the aim of combining the nutritional characteristics of wheat with drought and salinity stress tolerance, plus rust resistance of rye [73]. Aluminum tolerance of disomic hexaploid and octoploid triticale showed variable contribution of its parental species and could not be fully expressed in rye synthetic cultivars [74]. Chromosome set doubling in maize $\times$ teosinte hybrids improved biomass yield, tillering, and resistance to heat stress [16]. However, spotted stalk borer (Chillo partellus Swinhoe) resistance in the $\mathrm{F}_{1}$ interspecific maize $\times$ teosinte hybrids was not noticed because of the effect of the susceptible maize parent [75].

\section{Factor affecting The Success of Induced Polyploidy}

The data reviewed above showed some successful examples of about the experimentally obtained polyploids. However, forage breeders considered some decades ago induced polyploidy as an unconventional technique with high expectation and low realization [76]. According to earlier research, it may take many years from the first chromosome set doubling events to the final development of a superior new cultivar [76]. Lolium is a nice example showing that induced polyploidy brought commercial success of polysomic tetraploids of this species [77]. This is probably the best for a forage species for which this methodology has worked, but it has taken well over 50 years from the early doubling events to the point where polysomic tetraploid cultivars are now common place [61]. Tetraploid cultivars of Lolium multiflorum may have larger seed size, leaf size and length, plant height, seed head length when compared with its $2 \times$ species [78]. Seed mass of $4 \times$ accessions of Lolium species was $3.8 \mathrm{mg}$ (120 seeds) in comparison to $2.4 \mathrm{mg}$ (120 seeds) of the $2 \times$ cultivars [79]. The seed mass has been shown to affect seedling vigor and seedling morphological trait [79]. At cellular level, $4 \times$ cultivars of Lolium had faster cell elongation rate which increase the cell length, which results in the increase in the size of leaf tissue [80]. $4 \times$ tissues had 20 folds larger mesophyll and epidermal cells than in diploid cultivars [80]. DNA contents of $4 \times$ Lolium accessions

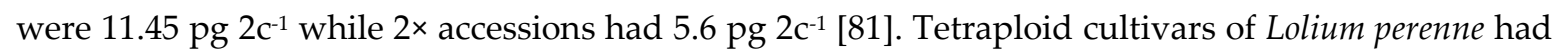
higher digestibility and water-soluble carbohydrates [82]. These $4 \times$ cultivars of Lolium species also offer several other advantages; i.e., act as cheaper source for cultivation than $\mathrm{F}_{1}$ hybrid seed, better tolerance to abiotic stress condition [35] (Table 4). Higher drought tolerance of $4 \times$ cultivar of Lolium multiflorum was due to increased production of antioxidants such as phenolics and enzymes which scavenge the reactive oxygen species under stress [83]. Tetraploid cultivars of Lolium perenne had an advantage over diploid in late heading cultivars for traits such as herbage mass ( $\left.\mathrm{kg} \mathrm{DM} \mathrm{ha}^{-1}\right)$ under low stocking rate while superior sward height, bulk density $\left(\mathrm{kg} \mathrm{m}^{-2}\right)$, leaf proportion under both low 
and high stocking rate [84]. Moreover, $4 \times$ intermediate heading Lolium cultivars had higher organic matter digestibility, leaf crude protein (\%), and cow fed on $4 x$ cultivars had higher milk yield ( $\mathrm{kg}$ day $\left.^{-1}\right)$, solid corrected milk yield $\left(\mathrm{kg}^{-1 a y}{ }^{-1}\right)$ under both high and low stocking rate while late heading $4 \times$ Lolium cultivars were superior under low stocking rates for same traits [84]. Fat, protein and lactose yield $\left(\mathrm{kg}\right.$ day $\left.{ }^{-1}\right)$ was higher in animals fed on $4 \times$ Lolium cultivars under both high and low stock conditions [84].

In a top cross mating design, tetraploid open pollinated cultivars (female) were crossed with newly generated induced tetraploid plants (male testers), and several uniform families were established and out of which one family had better dry matter yield and water-soluble carbohydrate but lower ground cover over the check for three years [35]. In a trial over 3 years, late heading $4 \times$ cultivars of Lolium perenne such as Ba13798 and Aberbite had clear cut yield advantage for total dry matter yield $\left(\mathrm{kg} \mathrm{ha}^{-1}\right)$, dry matter digestibility, water soluble carbohydrate but lower in crude protein and ground cover when compared with late heating $2 \times$ cultivars [35]. The $4 \times$ Lolium cultivar 'Green gold' had dry matter yield advantage of $7 \%$ per harvest and superior quality trait such as water-soluble carbohydrates over $2 \times$ AbderDart cultivar [85]. However, $2 \times$ cultivars had higher ensilability [85]. In comparison for the grazing preference among $2 \times$ and $4 \times$ cultivars of Lolium, animal grazed higher quantity of dry matter $\left(1380 \mathrm{~kg} \mathrm{ha}^{-1}\right)$ vs. diploid cultivar $\left(895 \mathrm{~kg} \mathrm{ha}^{-1}\right)$ and spent more time $(10 \%)$ in grazing of $4 \times$ cultivars [86]. Higher cattle preference for $4 \times$ cultivars was due to high leaf proportion and leaf soluble carbohydrates [86]. A study showed higher water-soluble carbohydrate and crown rust susceptibility for $4 \times$ cultivars in Lolium [87]. Recently a $4 \times$ late maturing cultivar "FL-Red" has been released for cultivation with improved resistance to crown rust and high sustainable yield through selection [88]. Seed mixture of $4 \times$ Lolium with Trifolium repens also had better dry matter yield and also with other species. Induced tetraploidy had similar effect on water-soluble carbohydrates of $4 \times$ Lolium cultivars as that for recurrent selection for higher water-soluble carbohydrates in $2 \times$ diploid cultivars [89]. Water-soluble content could be increased either by intensifying the favorable alleles through recurrent selection or increasing the copy number of alleles in $4 \times$ bred germplasm [89].

Slow progress of induced polyploidy after early induction of the chromosome set doubling event of chromosome is the major hindrance of low success rate of polyploidy breeding. The mixoploid condition $(2 \times, 3 \times$ and $4 \times)$ in freshly developed material and subsequent generation reduced the performance, stability and fertility of induced polyploids [90], which was regarded as a major hindrance for the commercialization of polyploidy species. However, selection of pure and stable polyploidy genotypes in advanced generation can improve the performance of the induced polyploid species. It was observed that selection for several generations could lead to the increased frequency of polysomic tetraploid plants in Lolium multiflorum [90]. Lolium species probably showed better results of the selection and thus was finally commercialized as polysomic tetraploid species [61].

The stabilization of the chromosome number in induced polyploidy require time and may depend on accurately identifying stable offspring regarding chromosome number. Tools such as flow cytometry may be exploited to screen various hybrid-derived offspring with stable chromosome number. Molecular techniques which may accurately determines within genome and epigenome changes such as epigenetic interactions, down and up regulation of key genes related to yield and quality may help to improve the performance of the neo-polyploids. 


\section{Conclusion}

Polyploidy is widespread phenomenon among grass and legume forages. Research has shown that polyploid species have greater biomass yield, persistence, and regrowth after grazing, and better tolerance to abiotic stresses than diploid species. Methods for induced polyploidy have been developed to increase biomass yield and improve foliage quality. The stability of induced polyploidy may be improved by selection for balanced chromosome pairing and disjunction. Induced polyploidy has also been used to increase fertility of interspecific hybrids between two cross-incompatible species. Research results suggested that this polyploidy approach should be exploited in forage breeding without any negative consequences. However, the breeding of new cultivars using this approach needs to shorten the lengthy selection cycles from early chromosome doubling stabilize of neo-polyploidy, and address both the poor fertility and loss of vigor in following generations of neo-polyploidy.

\section{Conflicts of interest}

The authors declare no conflicts of interest.

\section{Funding statement}

This research did not receive any specific funding.

\section{Author Contributions}

Conceived the idea and wrote some sections, S.R.; made technical corrections in text and figures, updated technical terms and added new text in all drafts, elaborate sections and wrote new sections, R.O.; corrected $1^{\text {st }}$ draft of the article and provided technical inputs, D.P.M; corrected several sections and added new section, W.R.C; added new references throughout the text, W.K.; read manuscript and provided input in figures M.S., helped in writing first draft of article, U.W.; and made technical input in all drafts, S.W.H. All authors have read and agreed to the published version of the manuscript.

\section{References}

1. Chen, Z.J. Molecular mechanisms of polyploidy and hybrid vigor. Trends Plant Sci. 2010, 15, 5771.

2. Shimizu-Inatsugi, R.; Terada, A.; Hirose, K.; Kudoh, H.; Sese, J. Shimizu, K.K. Plant adaptive radiation mediated by polyploid plasticity in transcriptomes. Mol. Ecol. 2017, 26, 193 - 207.

3. Estep, M. C.; McKain, M.R.; Diaz, D.V.; Zhong, J.; Hodge, J.G.; Hodkinson, T.R. et al. Allopolyploidy, diversification, and the Miocene grassland expansion. Proceedings of the National Academy of Sciences USA, 2014, 111, 15149-15154.

4. Randhawa, M. S.; Singh, R. P.; Dreisigacker, S.; Bhavani, S.; Huerta-Espino, J.; Rouse, M. N.; Sandoval-Sanchez, M. Identification and validation of a common stem rust resistance locus in two bi-parental populations. Front. Plant Sci. 2018, 9: 1788.

5. Rao, S.; Tian, Y.; Xia, X. et al. Chromosome doubling mediates superior drought tolerance in Lycium ruthenicum via abscisic acid signaling. Hort. Res. 2020, 7, 40. doi: 10.1038/s41438-020-0260-1

6. Te Beest, M.; Le Roux, J. J.; Richardson, D. M.; Brysting, A. K.; Suda, J.; Kubešová, M.; Pyšek, P. The more the better? The role of polyploidy in facilitating plant invasions. Annal. Bot. 2012, 109(1), 19-45. 
7. Venial, L.R., Mendonça, M.A.C., Amaral-Silva, P.M., Canal, G.B., Passos, A.B.R.J., Ferreira, A., Soares, T.C.B., Clarindo, W.R. Autotetraploid Coffeacanephora and auto-alloctaploid Coffeaa rabicafrom in vitro chromosome set doubling: new germplasms for Coffea. Front. Plant Sci. 2020, 11, 154. doi: $10.3389 /$ fpls.2020.00154

8. Dhooghe, E.; Van Laere, K.; Eeckhaut, T.; Leus, L.; Van Huylenbroeck, J. Mitotic chromosome doubling of plant tissues in vitro. Plant Cell, Tissue Organ Cult. 2011, 104, 359-373.

9. Bretagnolle, F.A.; Thompson, J.D. Gametes with the somatic chromosome number: mechanisms of their formation and role in the evolution of autopolyploid plants. New Phytol. 1995, 129, 1-22.

10. Sattler, M.C.; Carvalho, C.R.; Clarindo, W.R. The polyploidy and its key role in plant breeding. Planta, 2016, 243: $281-296$.

11. Ciprian-Salcedo, G.C.; Jimenez-Davalos, J.; Zolla, G. Flow-cytometry applications in plant breeding. Rev. Perua Biol. 2020, 27(1), 79-84.

12. Rauf, S.; Sienkiewicz-Paderewska, D.; Malinowski, D.P.; Hussain, M.M.; Niazi, I.A.K.; Kausar, M. Forages: ecology, breeding objectives and procedure, in Advances in plant breeding strategies: agronomic, abiotic and biotic stress traits, ed J.M. Al-Khayriet al. (Cham: Springer), 2016,149-201.

13. Stebbins, G.L. The origin of the complex of Bromus carinatus and its phylogeographic implications. Contributions from the Gray Herbarium of Harvard University, 1947, 165: 42-55.

14. Stebbins, G.L. Chromosomes and evolution in the genus Bromus (Gramineae). Botanische Jahrbücherfür Systematik, Pflanzengeschichte und Pflanzengeographie, 1981, 102: 359-379.

15. Rao, S.R.; Kumar, A.; Purohit, J.,; Khedasana, R.; Bewal, S. Cytogenetical investigations in colchicine induced tetraploids of Cyamopsis tetragonoloba L. Czech J. Genet. Plant Breed. 2010, 45, 143-154.

16. Niazi, I.A.K.; Rauf, S.; Teixeira da Silva, J.A.; Iqbal, Z.; Munir, H. Induced polyploidy in intersubspecific maize hybrids to reduce heterosis breakdown and restore reproductive fertility. Grass Forage Sci. 2015, 70, 682-694.

17. Corneillie, S.; De Storme, N.; Van Acker, R.; Fangel, J.U.; De Bruyne, M.; De Rycke, R.; Boerjan, W. Polyploidy affects plant growth and alters cell wall composition. Plant Physiol, 2019, 179, 74-87.

18. Ardabili, G.S.; Zakaria, R.A.; Zare, N. In vitro induction of polyploidy in Sorghum bicolor

L. Cytologia, 2015, 80, 495-503.

19. Poosamart, W.; Siniri, N.; Simia, S. Effects of colchicine concentration level and soaking period to induce polyploid mutation on five forage sorghum (Sorghum bicolor L. Moench) cultivars. J. Mahanakorn Veter. Med. 2015, 10: 99--110.

20. Simioni, C.; Valle, C.B. Meiotic analysis in induced tetraploids of Brachiari Adecumbens Stapf. Crop Breed. Appl. Biotech. 2011, 11: 43-49.

21. De Souza-Kaneshima, A.M.; Simioni, C.; Felismino, M.F.; Mendes-Bonato, A.B.; Risso-Pascotto, C.; Pessim et al. Meiotic behaviour in the first interspecific hybrids between Brachiaria brizantha and Brachiaria decumbens. Plant Breed. 2010, 129, 186-191.

22. Pagliarini, M.S.; Carneiro Vieira, M.L.; Borges do Valle, C. Meiotic behavior in intra-and interspecific sexual and somatic polyploid hybrids of some tropical species, in Meiosis molecular mechanisms and cytogenetic diversity. 2012, Available from: https://www.intechopen.com/books/meiosis-molecular-mechanisms-and-cytogenetic-diversity/mei otic-behavior-in-intra-and-interspecific-tetraploid-sexual-and-somatic-hybrids-of-some-tropical-s [Last access 28 $8^{\text {th }}$ October 2019] 
23. Yu, C.Y.; Kim, H.S.; Rayburn, A.L.; Widholm, J.M.; Juvik, J.A. Chromosome doubling of the bioenergy crop, Miscanthus $\times$ giganteus. GCB Bioenergy 2009, 1: 404-412.

24. Faleiro, F.G.; Kannan, B.; Altpeter, F. Regeneration of fertile, hexaploid, interspecific hybrids of elephantgrass and pearl millet following treatment of embryogenic calli with antimitotic agents. Plant Cell, Tissue Organ Cult. 2016, 124, 57-67.

25. Dabkevičienè, G.; Statkevičiūtè G.; Mikaliūnienè, J.; Norkevičienė, E.; andKemešytè, V. Production of Trifolium pratense $\mathrm{L}$. and T. hybridum L. tetraploid populations and assessment of their agrobiological characteristics. Zemdir. Agric., 2016, 103, 377-384.

26. Dabkevičienė, G.; Kemešytė, V.; Statkevičiūtė, G.; Lemežienė, N.; Brazauskas, G. Autopolyploids in fodder grass breeding: induction and field performance. Spanish J. Agric. Res. 2017, 15(4), 20.

27. Castillo, A.; Lopez Carro, B.; Dalla Rizza, M.; Reyno, R. Use of in vitro methods to induce autotetraploids in the native forage legume Trifolium polymorphum. In VII International Symposium on Production and Establishment of Micropropagated Plants, 2017, 1224 (pp. 73-80).

28. Silva, A.J.; Carvalho, C.R.; Clarindo, W.R. Chromosome set doubling and ploidy stability in synthetic auto- and allotetraploid of Eucalyptus: from in vitro condition to the field. Plant Cell, Tissue Organ Cul. 2019, 138, 387-394.

29. Dirihan, S.; Terho, P.; Helander, M.; Saikkonen, K. Efficient analysis of ploidy levels in plant evolutionary ecology. Caryologia, 2013, 66, 251-256.

30. Fu, L.; Zhu, Y.; Li, M. et al. Autopolyploid induction via somatic embryogenesis in Lilium distichum Nakai and Lilium cernuum Komar. Plant Cell, Tissue Organ Cult. 2019, 139, 237-248.

31. Lee, Y.I.; Tseng, Y.F.; Lee, Y.C.; Chung, M.C. Chromosome constitution and nuclear DNA content of Phalaenopsis hybrids. Sci. Hortic. 2020, 262, 109089.

32. Yun, L.; Yun, J.; Li, J.; Zheng, L., Zhao, W., Qi, L. Callus polyploidy induction and identification of Russian wild ryegrass. Acta Pratac. Sinica, 2010, 19, 126-131.

33. Joshi, P.; Verma, R.C. High frequency production of colchicine induced autotetraploids in faba bean (Viciafaba L.). Cytologia 2004, 69, 141-147.

34. Abd El-Naby, Z.M.; Mohamed, N.A.; Radwan, K.H.; El-Khishin, D.A. Colchicine induction of polyploidy in Egyptian clover genotypes. J. Amer. Sci. 2012, 8, 221-227.

35. Wilkins, P. W.; Lovatt, J.A. Gains in dry matter yield and herbage quality from breeding perennial ryegrass. Irish J. Agric. Food Res. 2011, 23-30.

36. Dhawan, O.P.; Lavania, U.C. Enhancing the productivity of secondary metabolites via induced polyploidy: a review. Euphytica 1996, 87, 81-89.

37. Tulay, E., Unal, M. Production of colchicine induced tetraploids in Vicia villosa roth. Caryologia, 2010, 63: 292-303.

38. Dabkevičienė, G.; Kemešytè, V.; Lemežienè, N.; Butkutė, B. Production of slender cocksfoot (Dactylis polygama H.) tetraploid populations and their assessment for agromorphological characteristics. Zemdir. Agric. 2013, 100, 303-310.

39. Balocchi, O.A.; López, I.F. Herbage production, nutritive value and grazing preference of diploid and tetraploid perennial ryegrass cultivars (Lolium perenne L.). Chil. J. Agric. Res. 2009, 69, 331-339.

40. Zielinski, M. L.; Scheid, O.M. Meiosis in polyploid plants. In Polyploidy and genome evolution (pp. 33-55), 2012, Springer, Berlin, Heidelberg. 
41. Comai, L. The advantages and disadvantages of being polyploid. Nat. Rev. Genet. 2005, 6, 836846.

42. Skiebe, K., Seliger, P. Isoenzymes and their importance for breeding autopolyploids. Plant Breed, 1990, 105(2), 106-111.

43. Valizadeh, M.; Mohayeji, M.; Yasinzadeh, N.; Nasrullazadeh, S.; Moghaddam, M. Genetic diversity of synthetic alfalfa generations and cultivars using tetrasomic inherited allozyme markers. J Agric. Sci. Tech. 2011, 13(3), 425-430.

44. Corts, M.R., Morales, M.C., Martinez, C. Variation of PGM and IDH isozymes for identification of alfalfa varieties. Euphytica, 2000, 112(2), 137-143.

45. Jalaly, H.M.; Valizadeh, M.; Ahmadi, M.; Nabizadeh, H.; Moharramnejad, S.; Moghaddam, M. Discrimination of alfalfa half-sib families by allozyme banding pattern and its relationship with forage yield attributes. J. Biodiv. Environ. Sci. 1990, 6 (1): 344-350.

46. Fjellstrom, R.G., Steiner, J.J., Beuselinck, P.R. Tetrasomic linkage mapping of RFLP, PCR, and isozyme loci in Lotus corniculatus L. Crop Sci. 2003, 43(3), 1006-1020.

47. Diwan, N.; Bouton, J.H.; Kochert, G.; Cregan, P.B. Mapping of simple sequence repeat (SSR) DNA markers in diploid and tetraploid alfalfa. Theoret. Appl. Genet. 2000, 101(1-2), 165-172.

48. Julier, B.; Flajoulot, S.; Barre, P.; Cardinet, G.; Santoni, S.; Huguet, T.; Huyghe, C. 2003. Construction of two genetic linkage maps in cultivated tetraploid alfalfa (Medicago sativa) using microsatellite and AFLP markers. BMC Plant Biol. 3(1), 9.

49. Stein, J.; Quarin, C.L.; Martínez, E.J.; Pessino, S.C.; Ortiz, J.P.A. Tetraploid races of Paspalum notatum show polysomic inheritance and preferential chromosome pairing around the apospory-controlling locus. Theoret. Appl Genet. 2004, 109(1), 186-191.

50. Begheyn, R.F.; Lübberstedt, T.; Studer, B. Haploid and doubled haploid techniques in perennial ryegrass (Lolium perenne L.) to advance research and breeding. Agronomy 2016, 6, 60.

51. Molin, W.T.; Meyers, S.P.; Baer, G.R.; Schrader, L.E. Ploidy effects in isogenic populations of alfalfa. II. Photosynthesis, chloroplast number, ribulose-1,5-bisphosphate carboxylase, chlorophyll, and DNA in protoplasts. Plant Physiol. 1982, 70, 1710-1714.

52. Mo, L; Chen, J.; Lou, X.; Xu, Q.; Dong R.; Tong Z.; Huang H.; Lin, E.. Colchicine-induced polyploidy in Rhododendron fortune Lindl. Plants 2020, 9(4), 424. doi: 10.3390/plants9040424

53. Pei, Y.; Yao, N.; He, L.; Deng, D.; Li, W.; Zhang, W. Comparative study of the morphological, physiological and molecular characteristics between diploid and tetraploid radish (Raphunas sativus L.). Scient. Hort. 2019, 257, 108739. doi: 10.1016/j.scienta.2019.108739

54. Capomaccio, S.; Veronesi, F.; Rosellini, D. Polyploidization and gene expression in Medicago sativa, in Sustainable use of genetic diversity in forage and turf breeding, ed C. Huyghe (Springer, Dordrecht) 2010, 397-401.

55. Santos, F. C.; Guyot, R.; Do Valle, C. B.; Chiari, L.; Techio, V. H.; Heslop-Harrison, P.; Vanzela, A.L.L. (2015). Chromosomal distribution and evolution of abundant retrotransposons in plants: gypsy elements in diploid and polyploid Brachiaria forage grasses. Chromosome Res. 2015, 23(3), 571-582.

56. Oberprieler, C.; Talianova, M.; Griesenbeck, J. Effects of polyploidy on the coordination of gene expression between organellar and nuclear genomes in Leucanthemum Mill. (Compositae, Anthemideae). Ecol. Evol. 2019, 9, 9100-9110. 
57. Murashige, T.; Skoog, F. A revised medium for rapid growth and bioassays with tobacco tissue cultures. Physiol. Plant. 1962, 15, 473-497. doi: 10.1111/j.1399-3054.1962.tb08052.x

58. Yoon, S.; Aucar, S.; Hernlem, B.J.; Edme, S.; Palmer, N.; Sarath, G. et al. Generation of octaploid switchgrass by seedling treatment with mitotic inhibitors. BioEnergy Res. 2017, 10: 344-352.

59. Mendes-Bonato, A.B.; Felismino, M.F.; Kaneshima, A. S.; Pessim, C.; Calisto, V.; Pagliarini, M.S.; do Valle, C.B. Abnormal meiosis in tetraploid genotypes of Brachiaria brizantha (Poaceae) induced by colchicine: its implications for breeding. J. Appl. Genet. 2009, 50, 83-87.

60. Dos Reis, G.B.; Ishii, T.; Fuchs, J.; Houben, A.; Davide, L.C. Tissue-specific genome instability in synthetic interspecific hybrids of Pennisetum purpureum (Napier grass) and Pennisetum glaucum (pearl millet) is caused by micronucleation. Chromosome Res. 2016, 24(3), 285-297.

61. Pereira, R.C.; Ferreira, M.T.M.; Davide, L.C.; Pasqual, M.; Mittelmann, A.; V.H. Techio. Chromosome duplication in Loliummultiflorum Lam. Crop Breed. Appl. Biotech. 2014, 14: 251-255.

62. Simioni, C.; Wittmann, M. T. S.; Dall, M.; Guerra, D. Selection for increasing 2 n gamete production in red clover. Crop Breed. Appl. Biotech. 2004, 4(4), 217-220.

63. Niazi, I.A.K. Evaluation of Zea mays $\times$ Zea mexicana for high fodder yield. Ph.D. Dissertation, 2016, University of Sargodha, Pakistan.

64. Nair, R.M. Developing tetraploid perennial ryegrass (Lolium perenne L.) populations. New Zea. J. Agric. Res. 2004, 47, 45-49.

65. Pereira, R.C.; Davide, L.C.; Techio, V.H.; Timbó, A.L.O. Chromosome doubling of grasses: an alternative to plant breeding. Ciência Rural, 2012, 42: 1278-1285.

66. Baduel, P.; Bray, S.; Vallejo-Marin, M.; Koláŕ, F.; Yant, L. The "polyploid hop": shifting challenges and opportunities over the evolutionary lifespan of genome duplications. Front. Ecol. Evol. 2018, $6,117$.

67. Frank, A.B., J.D. Berdahl. Gas exchange and water relations in diploid and tetraploid Russian wildrye. Crop Sci. 2001, 41, 87-92.

68. Ribotta, A.N.; Griffa, S.M.; Díaz, D.; Carloni, E.J.; Colomba, E.L.; Tommasino, E. A.; Grunberg, K. Selecting salt-tolerant clones and evaluating genetic variability to obtain parents of new diploid and tetraploid germplasm in rhodesgrass (Chloris gayana K.). South African J. Bot. . 2013, 84, 88-93.

69. Tozer, K.N.; Carswell, K.; Griffiths, W.M.; Crush, J.R.; Cameron, C.A; Chapman, D.F. et al. Growth responses of diploid and tetraploid perennial ryegrass (Lolium perenne) to soil-moisture deficit, defoliation and a root-feeding invertebrate. Crop Pasture Sci. 2017, 68: 632-642.

70. Sugiyama, S. Differentiation in competitive ability and cold tolerance between diploid and tetraploid cultivars in Lolium perenne. Euphytica, 1998, 103, 55-59.

71. Chandra, A.; Dube, A. Assessment of ploidy level on stress tolerance of Cenchrus species based on leaf photosynthetic characteristics. Acta Physiol. Plant. 2009, 31, 1003-1013.

72. Wang, Z.; Wang, M.; Liu, L.; Meng, F. Physiological and proteomic responses of diploid and tetraploid black locust (Robinia pseudoacacia L.) subjected to salt stress. Inte. J. Mol. Sci. 2013, 14(10), 20299-20325.

73. Arseniuk, E. Triticale abiotic stresses - An overview. Commun. Agri. Appl. Biol. Sci. 2015, 79, 82100.

74. Ryan, P.; Dong, D.; Wendler, N.; Mühling, K.H.; Liu, J.; Xu, M. et al. Assessing how the aluminum-resistance traits in wheat and rye transfer to hexaploid and octoploid triticale (×Tritosecale Wittmack). Front. Plant Sci. 2018, 9: 1334. 
75. Niazi I.A.K.; Avais, R.; Rauf, S.; Teixeira da Silva, J.A.; Afzal, M. Simultaneous selection for stem borer resistance and forage related traits in maize (Zea mays ssp. mays L.) $\times$ teosinte (Zea mays ssp. mexicana L.) derived populations. Crop Prot. 2014, 57: 27-34.

76. Dewey, D.R. Some applications and misapplications of induced polyploidy to plant breeding. In Polyploidy (Springer, Boston, MA), 1980, 445-470.

77. Den Nijs, A.P.M.; Stephenson, A.G. Potential of unreduced pollen for breeding tetraploid perennial ryegrass. In Sexual reproduction in higher plants (Springer, Berlin, Heidelberg), 1988, 131136.

78. Rios, E. F.; Kenworthy, K. E.; Munoz, P.R. Association of phenotypic traits with ploidy and genome size in annual ryegrass. Crop Sci. 2015, 55(5): 2078-2090.

79. Smith, K. F.; McFarlane, N. M.; Croft, V. M.; Trigg, P. J.; Kearney, and G.A. The effects of ploidy and seed mass on the emergence and early vigour of perennial ryegrass (Lolium perenne L.) cultivars. Aust. J. Exp. Agric. 2003, 43(5), 481-486.

80. Sugiyama, S.I. Polyploidy and cellular mechanisms changing leaf size: comparison of diploid and autotetraploid populations in two species of Lolium. Ann. Bot. 2005, 96(5): 931-938.

81. Wang, Y.; Bigelow, C. A.; Jiang, Y.; Ploidy level and DNA content of perennial ryegrass germplasm as determined by flow cytometry. HortSci. 2009, 44(7), 2049-2052.

82. Burns, G.A.; Gilliland, T.J.; Grogan, D.; O' Kiely, P. Comparison of the agronomic effects of maturity and ploidy in perennial ryegrass. Grassland a European Res. 2012, 349-351.

83. Akinroluyo, O.K.; Jaškūnè, K.; Kemešytė, V.; Statkevičiūtè, G. 2020. Drought stress response of Westerwolths ryegrass (Lolium multiflorum ssp. multiflorum) cultivars differing in their ploidy level. Zemdir. Agric. 2020, 107(2): 221-230.

84. O'Donovan, M.; Delaby, L.A. comparison of perennial ryegrass cultivars differing in heading date and grass ploidy with spring calving dairy cows grazed at two different stocking rates. Anim. Res. 2005, 54(5): 337-350.

86. Solomon, J.K.; Macoon, B.; Lang, D. J.; Vann, R. C., Ward, S. 2014. Cattle grazing preference among tetraploid and diploid annual ryegrass cultivars. Crop Sci. 2014, 54(1): 430-438.

87. Hume, D.E.; Hickey, M.J.; Lyons, T.B.; Baird, D. B. Agronomic performance and water-soluble carbohydrate expression of selected ryegrasses at two locations in New Zealand. New Zeal. J. Agric. Res. 2010, 53(1), 37-57.

88. Kenworthy, K.E.; Reith, P.E.; Prine, G.M.; Blount, A.R.; Quesenberry, K.H. Registration of 'FL Red', a later-maturing tetraploid annual ryegrass. J. Plant Reg. 2017, 11(1), 46-50.

89. Smith, K.F.; Simpson, R.J.; Culvenor, R.A.; Humphreys, M.O.; Prud'Homme, M.P., Oram, R.N. The effects of ploidy and a phenotype conferring a high water-soluble carbohydrate concentration on carbohydrate accumulation, nutritive value and morphology of perennial ryegrass (Lolium perenne L.). J. Agric. Sci. 2001, 136(1): 65-74.

90. Pereira, R.C.; Santos, N.D.S.; Bustamante, F.D.O.; Mittelmann, A.; Techio, V.H. Stability in chromosome number and DNA content in synthetic tetraploids of Lolium multiflorum after two generations of selection. Ciência Rural 2017, 47: 2.

91. Campos, J.M.S.; Davide, L.C.; Salgado, C.C.; Santos, F.C.; Costa, P.N.; Silva, P.S.; Pereira, A.V. In vitro induction of hexaploid plants from triploid hybrids of Pennisetum purpureum and Pennisetum glaucum. Plant Breed. 2009, 128, 101-104. 
92. Ishigaki, G.; Gondo, T.; Suenaga, K.; Akashi, R. Induction of tetraploid ruzigrass (Brachiaria ruziziensis) plants by colchicine treatment of in vitro multiple-shoot clumps and seedlings. Grassl Sci. 2009, 55, 164-170.

93. Głowacka, K.; Jeżowski, S.; Kaczmarek, Z. In vitro induction of polyploidy by colchicine treatment of shoots and preliminary characterisation of induced polyploids in two Miscanthus species. Ind. Crops Prod. 2010, 32(2), 88-96.

94. Timbó, A.L.D.O.; Souza, P.N.D.C.; Pereira, R.C.; Nunes, J.D.; Pinto, J.E.B.P.; SouzaSobrinho, F.D.; Davide, L.C. Obtaining tetraploid plants of ruzigrass (Brachiaria ruziziensis). R. Bras. de Zootec. 2014, 43: 127-131.

95. Bartek, M.S.; Hodnett, G.L.; Burson, B.L.; Stelly, D.M.; Rooney, W. L. Pollen Tube Growth After Intergeneric Pollinations of iap-Homozygous Sorghum. Crop Sci. 2012, 52(4), 1553-1560.

96. Yavari, S., Omidbaigi, R., \& Hassani, M. E. (2011). The effects of induction of autotetraploidy on the essential oil content and compositions of Dragonhead (Dracocephalum moldavica L.). J. Essent. Oil-Bear. Plants 14(4), 484-489.

97. Ardabili, G.S.; Zakaria, R.A.; Zare, N. Polyploidy induction and its effects on some morpho-physiologic characteristics in sorghum (Sorghum bicolor cv. KFS2). Iranian J. Crop Sci., 16, 151-164.

98. Pathak, S.; Malaviya, D. R.; Roy, A. K.; Dwivedi, K.; Kaushal, P.. Multifoliate Leaf Formation in Induced Tetraploids of Trifolium alexandrinum L. Cytologia, 2015; 80(1), 59-66.

99. Chaves, A.L.A.; Raquel, B.; Chiavegatto, M.L.; Gavilanes, F.R.G.B.; Vânia, H.T. Effect of polyploidy on the leaf epidermis structure of Cynodondactylon (L.) Pers. (Poaceae). Biologia 2018, 73, 1007-1013.

100. Sugiyama, S.I. Responses of shoot growth and survival to water stress gradient in diploid and tetraploid populations of Loliummultiflorum and L. perenne. Grassl. Sci. 2006, 52: 155-160.

101. Anwar, S. Genetic-phenotypic variability and correlation between morphology anatomy physiology characteristics and dry matter yield of polyploidized forage grasses under aluminum stressed condition. Animal Product. 2007, 9, 23-29.

102. Marzougui, N.; Boubaya, A.; Guasmi, F.; Elfalleh, W.; Touil, L.; Ferchichi, A.; Beji, M. Influence of artificial polyploidy on the salt stress tolerance of Trigonella foenum-graecum L. in Tunisia. Acta Bot. Gall. 2010, 157, 295-303.

103. Meng, H.B.; Jiang, S.S.; Hua, S.J.; Lin, X.Y.; Li, Y.L.; Guo, W.L.; Jiang, L.X. Comparison between a tetraploid turnip and its diploid progenitor (Brassica rapa L.): the adaptation to salinity stress. Agric. Sci. China 2011, 10, 363-375.

104. Chandra, A.; Dubey, A. Effect of ploidy levels on the activities of $\Delta 1$-pyrroline-5-carboxylate synthetase, superoxide dismutase and peroxidase in Cenchrus species grown under water stress. Plant Physiol. Biochem. 2010, 48, 27-34.

105. Franco, M.F.; Colabelli, M.N.; Petigrosso, L.R.; De Battista, J.P.; Echeverría, M.M. Evaluation of infection with endophytes in seeds of forage species with different levels of ploidy. New Zeal. J. Agric. Res. 2015, 58, 181-189.

106. Kemesyte, V.; Statkeviciute, G.; Brazauskas, G. Perennial ryegrass yield performance under abiotic stress. Crop Sci. 2017, 57, 1935-1940.

106. Kindiger, B.K. U.S. Patent No. 8,618,353. 2013. U.S. Patent and Trademark Office, Washington, DC. 
107. Nadel, D.; Nadel, M.; Nadel B. High yield maize derivatives. 2009. U.S. Patent Application $12 / 004,894$.

108. Lee, M. A.; Howard-Andrews, V.; Chester, M. Resistance of Multiple Diploid and Tetraploid perennial ryegrass (Lolium perenne L.) varieties to three projected drought scenarios for the UK in 2080. Agronomy, 2019, 9(3), 159. 